\title{
GLIMPSES INTO THE PREHISTORY OF NORTHEAST-HUNGARY The archaeological company Ásatárs Ltd was launched 15 years ago
}

\section{Zsolt GaLLina - GyöNGYi GuLYÁs}

Hungarian Archaeology, Vol. 8 (2019), Issue 3, pp. 12-19, https://doi.org/10.36338/ha.2019.3.3

We founded Ásatárs Ltd, the first company on the Hungarian archaeological scene specialized in professional archaeological fieldwork, in March, 2004. The founders were archaeologists with several years of experience in museums and fieldwork. At that time it was the first, entirely privately funded, independent enterprise dealing with complex archaeological activities. The company, now 15 years old, has been involved in archaeological tasks in 16 counties of Hungary. It led and organized excavations in 14 counties, performed fieldwork on ca. 1.5 million $\mathrm{m}^{2}$ as well as extrication of finds on approximately 2.5 million $\mathrm{m}^{2}$. In addition to arranging test and preventive excavations, we participated in planned excavations, experimental archaeological projects, as well as in the creation of exhibitions and archaeological and industrial places of memory. We took part in the processing and restoration of numerous finds and assemblages, and prepared publications on archaeological research. Three sites, central in the last two years of our company's work, are presented in this paper.

\section{LATE COPPER AGE ANIMAL AND HUMAN BURIALS AT GYÖNGYÖS}

The 2017 excavation conducted on an area of approximately 8 hectars of the planned Industrial Park No. 1 in the vicinity of Gyöngyös yielded remains of a settlement dated almost solely to the Baden horizon (3600/3500-2800/2700 BC). The area was cut into two by a dried-up, periodic riverbed. The riverbed first appeared in the northeastern corner of the excavation area, running from west to southwest, and after reaching the western segment of the lot it turned sharply towards the south. The site is located on two small elevations on the banks of the river. With its size and more than 1,300 features, this site is scarcely smaller than the largest Baden settlement in Hungary, excavated at Balatonőszöd. The excavation of the area continued in summer 2019, when the industrial park was expanded: the Dobó István Castle Museum of Eger in collaboration with Ásatárs Ltd. excavated another 404 features on a surface of almost 9 hectares. Thus, this settlement unearthed near Gyöngyös can be considered the largest Baden site in present-day Hungary.

A $200 \mathrm{~m}$ long section of an ancient riverved was observed on a surface below the present-day floor level. On the scraped surface the bed appeared in a width of 10-25 m, and a system of extraction pits was documented attached to the riverbed and its oxbow lake (Fig. 1).

This monumental complex was used in the Late Copper Age as a clay extracting pit system along the contemporary riverbank. On the higher surfaces, clusters of pits running along a north-south axis were observed; these groups of pits concentrated in areas of ca. $30 \times 30-40 \mathrm{~m}$ in size.

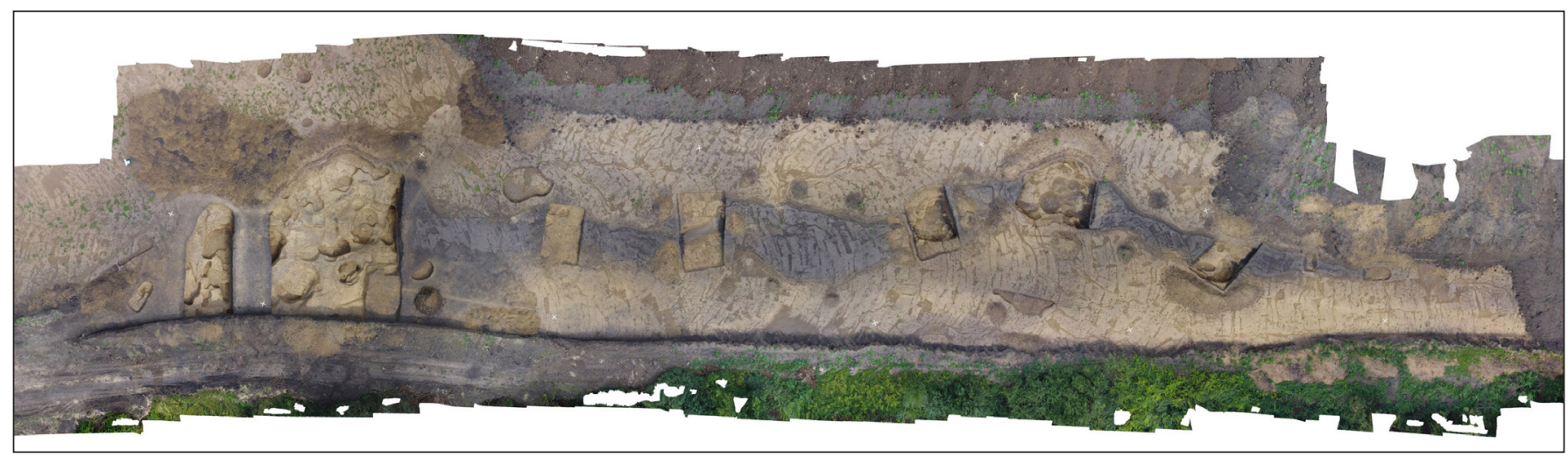

Fig. 1. Gyöngyös-Galagonyás-dülö, aerial photo of the clay extraction pit (by Kristóf László Rácz) 
Most of the animal burial pits were arranged in clusters. Almost complete skeletons of cattle were brought to light from ca. 100 pits. The cattle were „folded" into small and shallow pits or were laid in larger pits that had previously been abandoned. In several cases, the animals were placed in the pits with their legs under their bodies, and therefore, they were most likely slaughtered in the pits. Sometimes two cattle were buried in the same pit (Fig. 2). Cattle were placed into pits in various ways (lying on their left or right side, with legs under ther bodies, or on their back), which may indicate that these customs of deposition had diverse symbolic meanings and these burials can be considered sacrificial pits or bothroi (HoRVÁth, 2007, p. 124).

In addition to cattle burials, the skeletal remains of many sheep/goats, and several pigs and dogs were

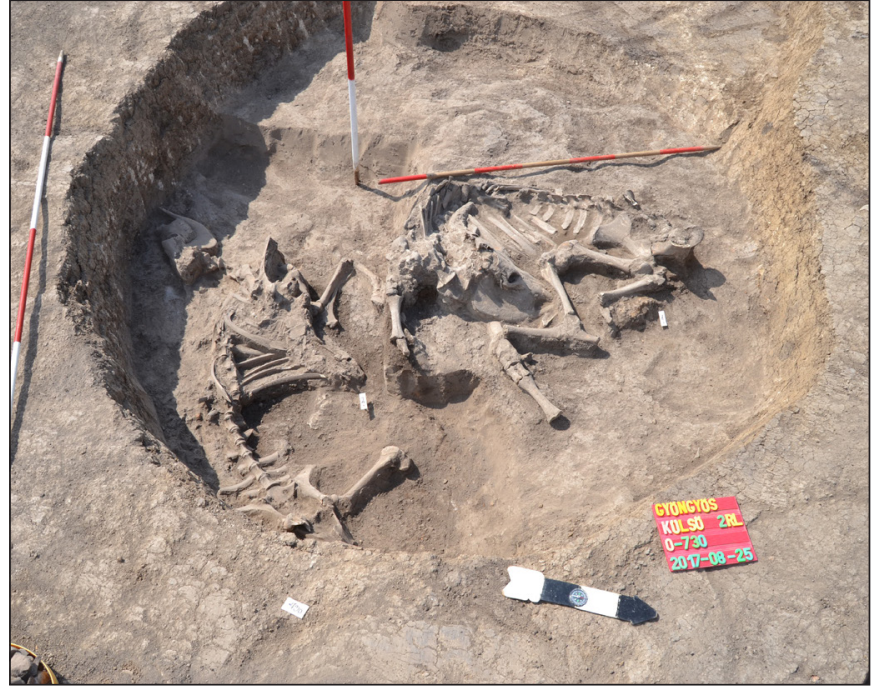

Fig. 2. Gyöngyös-Galagonyás-dülö, double cattle burial (Photo by Gyöngyi Gulyás) found. In one pit, five goat skeletons were recorded in two horizontal layers, and in another shallow pit six, spatially overlapping goat skeletons were discovered. However, these burials had less significance and were less unique than the cattle graves. Ruminants were often buried in mass graves, while swine and dogs were usually buried individually, and occasionally incomplete. Ruminants and swine may be interpreted as the remains of sacrificial feasts or grave goods intended for use in the afterlife (HoRVÁth, 2007, pp. 127-128).

Sacrificial pits containing similar cattle burial(s) were common in Hungary in the Late Copper Age. This site in Heves county is clearly outstanding in terms of animal burials: while at Balatonöszöd sacrificial animals were recovered only from 53 of the ca. 1,400 Late Copper Age features (HoRvÁth, 2004, p. 71; HoRváth, 2007, p. 145, Table 2), at Gyöngyös intact or partial animal remains were unearthed from almost 100 pits. Ritual activities in sacrificial pits, that is, the deposition of animal bodies, skeletal parts and vessels filled with food, are characteristic for this period.

In a number of features, however, human remains (complete and partial skeletons, or a few bones) were present alongside animal sacrifices suggesting agrarian rites. It seems that some animals, primarily cattle, were buried with greater respect than humans, who were sometimes simply thrown into a pit, or only certain body parts were inhumed. In the case of pits that yielded only pieces of the skull or other skeletal elements,

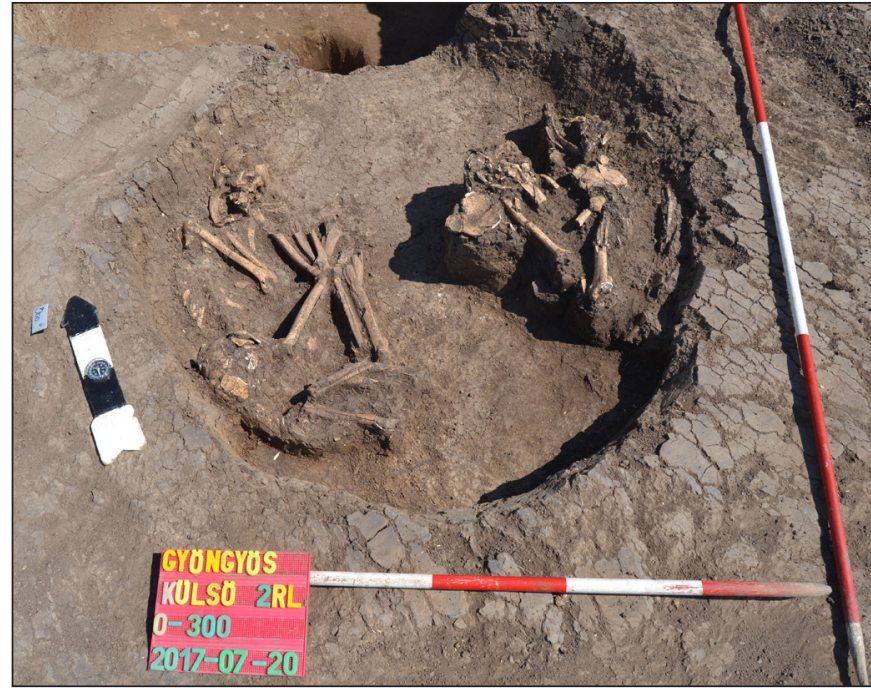

Fig. 3. Gyöngyös-Galagonyás-dülö, a pit with three human skeletons (Photo by Gyöngyi Gulyás) it cannot be excluded that post mortem rites were performed on them (HoRváth, 2004, p. 78).

It is uncertain whether these phenomena of sacrificing young individuals, animals and humans alike, may be interpreted as cruel rituals common to this period or as reactions to some unknown crisis the community had to face (such as war or an epidemic) (FÁBIÁN et al., 2017, p. 28). Various reasons are possible for burying human remains in pits; one can suspect ritual causes in the case of incomplete skeletons and individuals inhumed together with animals (HoRvÁtH 2004, p. 79). In case of graves without such exceptional phenonema, the causes for keeping the deceased away from the community may have been more mundane (e.g. low social status, disability, illness, epidemic). Human remains buried individually in pits without ritual phenomena 


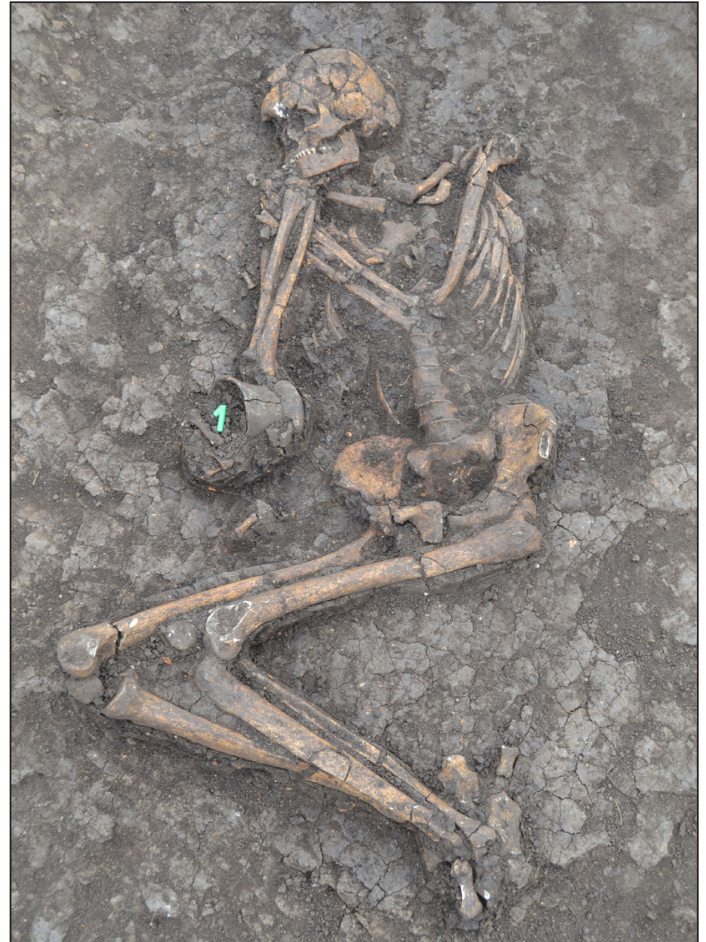

Fig. 4. Gyöngyös-Galagonyás-dülö, Late Copper Age burial (Photo by Gyöngyi Gulyás)

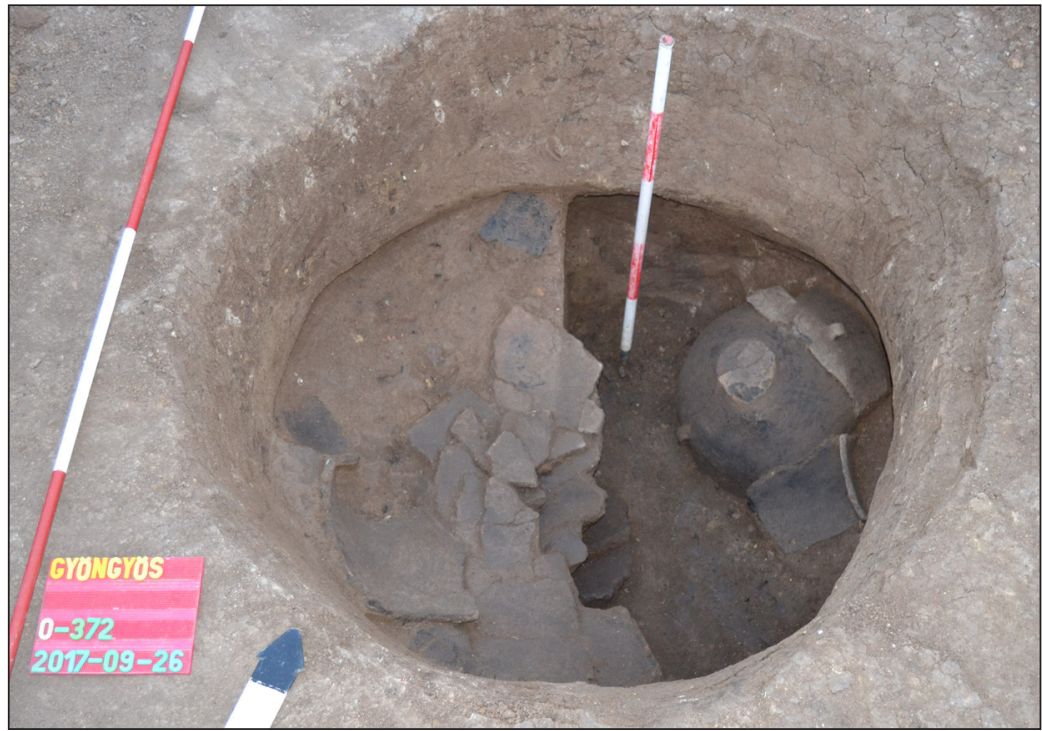

Fig. 5. Gyöngyös-Galagonyás-dülö, pit with complete and fragmented vessels (Photo by Gyöngyi Gulyás)

are scarce; most bodies recovered from storage or waste pits were deposited in a contracted position, without grave goods (Fig. 3). It is difficult to say whether members of the local community and/or foreigners were buried in such a manner.

Three regular pit burials were found a bit farther from a pit cluster. The bodies were found in a contracted position or lying on their backs; one person was interred with two pieces of pottery and some jewellery (pendant, needle) (Fig. 4).

Occasionally, complete vessels were found in or in the vicinity of pits that yielded animal and human burials (Fig. 5). These phenomena are undoubtedly manifestations of rituals, possibly fertility rites.

In conclusion, as the animal and human burials and the sacrificial pits yielding complete vessels were found in clusters, these can be interpreted as ritual phenomena. However, the remains only reveal the fact of the sacrifice, while the actors behind these rituals and their motivations remain unclear.

\section{THE URN CEMETERY OF THE BRONZE AGE KYJATICE CULTURE NEAR SZIKSZÓ}

During the preventive excavation associated with highway M30 in 2018, we explored $63,000 \mathrm{~m}^{2}$ at the site Szikszó-Gémeskúti-nyomás in Borsod County, bringing to light a total of 1,061 Prehistoric features. The site is located on a northwest-southeast oriented hillside, west of the Hernád river. A settlement associated with the Alföld Linear Pottery Culture (5500/5400-5000/4900 BC), dated to the Middle Neolithic, was found in the northern and western sections of the excavation area; settlement features were abundant on the periphery of the present-day settlement. Another large settlement, similar to the one in the Neolithic, existed here in the Late Bronze Age, in the southern part of the excavation area.

In the northeastern part of the excavated surface, parts of two Late Bronze Age cemeteries, altogether 50 graves, were discovered. The two grave clusters were almost $100 \mathrm{~m}$ from each other, while the distance between individual graves was 1-5 m. Burials were often found right below the topsoil; as intensive agriculture had a devastating impact on the Late Bronze Age floor level, these graves were severely damaged. Large graves with considerable quantities of pottery were deeper, and so these were almost intact. In general, the burial pits were round, oval or rectangular (Fig. 6). The rectangular ones were larger and deeper than the average. Neither plaster on their sides and bottom, nor quarry stones to cover them were found, although these were present at other sites (at Zagyvapálfalva: GuBA-VADAY, 2008, p. 18; Bercel-Sáfrány-hegy: GuBA, 2008, pp. 76-77).

In graves associated with the Kyjatice Culture (1100-750 BC), the remains of the dead were cremated on a funerary pyre, and placed in urns along with pieces of their attire and articles of personal use; the 
Zsolt Gallina - Gyöngyi Gulyás • Glimpses into the Prehistory of Northeast-Hungary

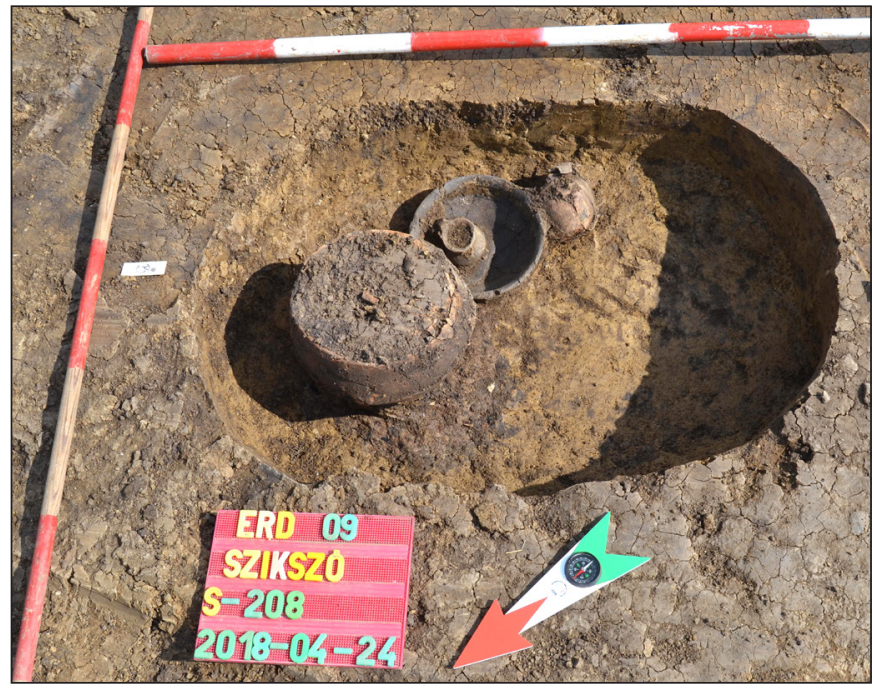

Fig. 6. Szikszó-Gémeskúti-nyomás, burial no. S-208 (Photo by Gyöngyi Gulyás) urns were usually covered with plates. Thereafter, the urns were placed into burial pits and surrounded with cups of various sizes, containing food and beverage intended for the afterlife. "Double" burials were observed several times; in these cases, two urns containing human remains were placed in a single pit (Fig. 7). This custom or phenomenon is not unique. In the Zagyvapálfalva cemetery, a number of urn clusters were observed: several urns containing human remains were deposited together in pits (GuBA-VADAY, 2008, Fig. 4. 4, Fig. 6).

The pits containing simple burials were just about the size of the urn. Findings in the intact graves suggest that the urns were sometimes left uncovered.

In addition to simple urn burials, urns accompanied by a varying number of other vessels were also present (Fig. 8). The pottery assemblage included

mostly plates, often used as covers and less often as accompanying vessels, as well as cups and mugs of different sizes. It seems that these associated vessels were not put on the funerary pyre but placed in the graves only when the urn was buried. In the southern urnfield, two burials yielded animal remains as well, probably the remains of food buried next to the urn.

Bronze jewellery was regularly found among the human remains. These included large, scythe-shaped needles with knobs, wire bracelets, bracelets with spiral ends, so-called Noppenrings, as well as lunular,

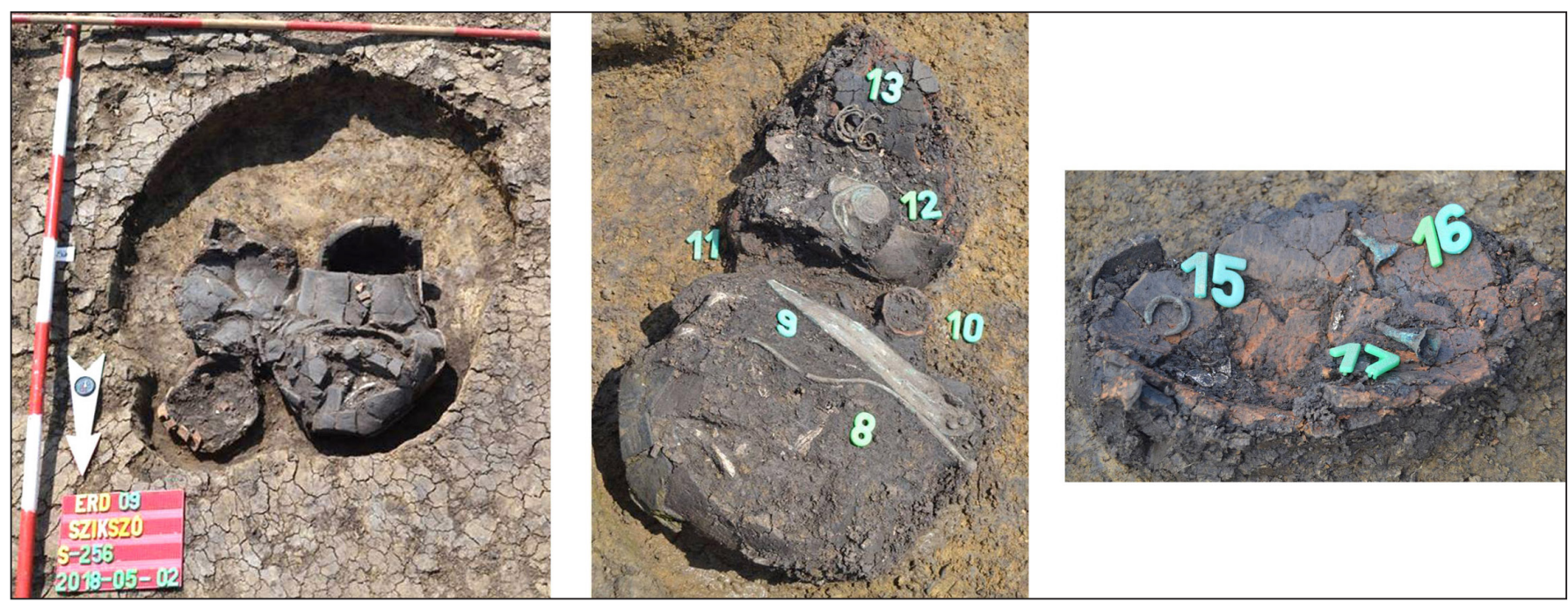

Fig. 7. Szikszó-Gémeskúti-nyomás, excavation phases of burial no. S-256 (Photo by Gyöngyi Gulyás)
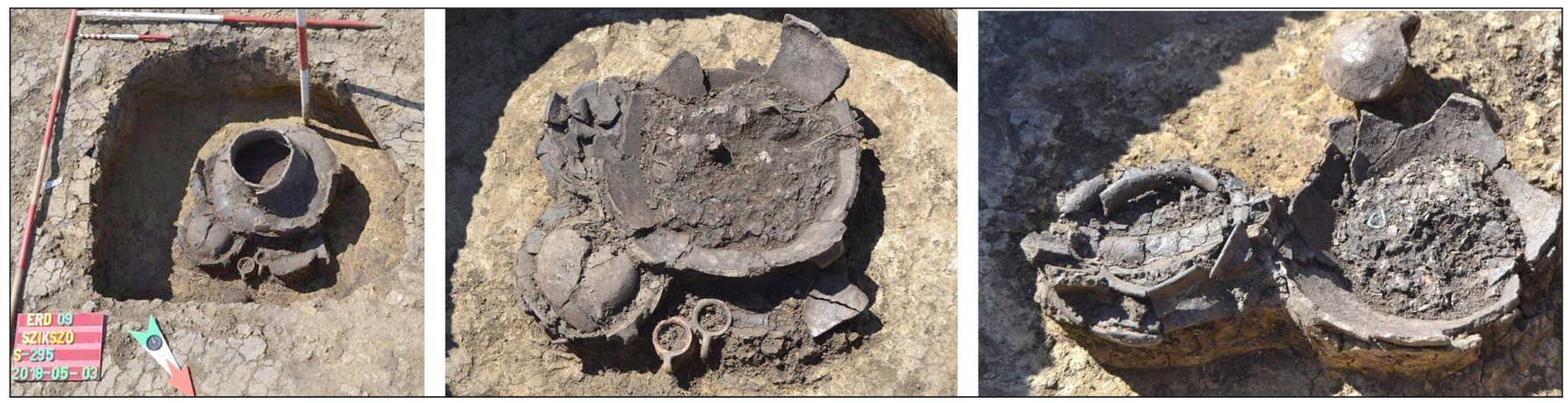

Fig. 8. Szikszó-Gémeskúti-nyomás, excavation phase of burial no. S-295 (Photo by Gyöngyi Gulyás) 


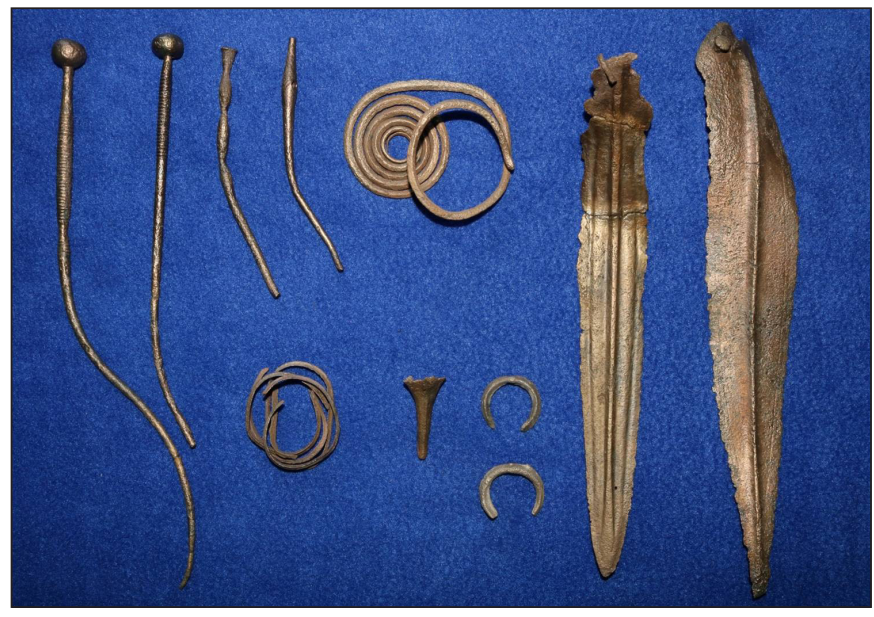

Fig. 9. Szikszó-Gémeskúti-nyomás, selected findings from the Late Copper Age urn cemetery (Restoration and photo by Róbert Móricz)

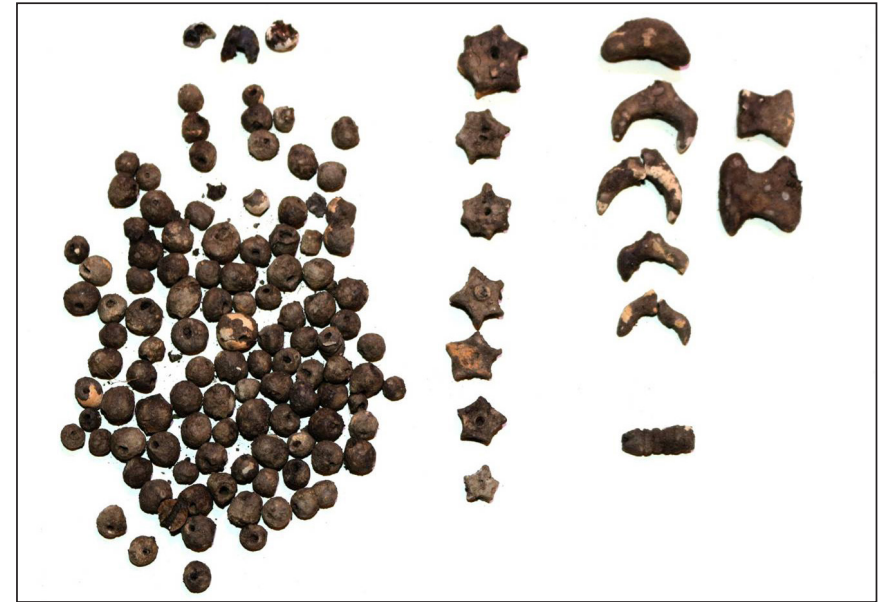

Fig. 10. kép: Szikszó-Gémeskúti-nyomás, clay beads recovered from a mug in burial no. $S$-256 (Photo by Gyöngyi Gulyás and Róbert Móricz)

double-spiral, tutulus-, and bell-shaped pendants. Three urns yielded bronze daggers equipped with fullers, slightly deformed by the heat on the funeral pyre (Fig. 9). One of the most interesting findings was discovered in a cup placed next to an urn. The cup contained clay beads, which were parts of a necklace; more than a hundred of these were round, two were reel-shaped, seven star-shaped, five crescent-shaped and one was cylindrical, imitating a coil (Fig. 10).

Analogies of the metal finds recovered from the Szikszó burials were found in the graves of Zagyvapálfalva (Hillebrand, 1929, Figs. 17-18; Guba-Vaday, 2008, Fig. 8) and Nagybátony (Patay, 1954, Figs. 10. $1-3,11-13)$.

\section{SCYTHIAN SETTLEMENT AT HALMAJ}

The site Halmaj-Kiskinizsi-dülö is situated west of the Hernád river. We excavated an area of 43,864 $\mathrm{m}^{2}$ here in 2018-2019, bringing to light 1,197 features. A Sythian settlement, one of the largest in the Carpathian Basin, was the most outstanding finding of this survey.

More than one hundred subterranean features and buildings, concentrated in clusters and dated to the Scythian period, were unearthed. Among these there were buildings supported by poles, foundation trenches, and pithouses with round or rounded rectangle-shaped ground plans. On the heavily eroded elevation in the southern part of the area, at least 51 pole-supported structures were documented (Fig. 11), along with 26 associated, narrow and shallow foundation trenches, some of which were divided into several sections by poles. These structures may be identified as palisade or foundation trenches, possible to interpret independently or as parts of a bigger structure supported by poles. Similar structures were depicted on contemporaneous Mongolian and Siberian petroglyphs as goatfolds (KuBAREV, et al., 2005, p. 590, Ric 100. $1,3-4,6)$.

In addition to the former buildings, 51 clustered, semi-subterranean structures were discovered, without traces of fireplaces (Fig. 12). Their layout is varied, but they belong to one of the following three groups: those with a circular or round groud plan; those with an almost rectangular ground plan with rounded corners, and larger ones with a regular regtangular ground plan. It is difficult to identify the location of the dwelling houses. However, Siberian, Mongolian, and Caucasian analogies (GARDNER \& BurentogtokH, 2018 , p. 12, Fig. 10) suggest that these settlements consisted of loghouses or yurts with fireplaces, which must have left no visible trace.

The pithouses must have served economic functions; their filling yielded at least one spindle whorl in almost all cases. Clay weights for fishing nets as well as grindstones were recovered from several settlement features, and some of the pits and buildings yielded animal bones with cutmarks. This suggests that local resources (wool, wheat, bone) were processed and stored in these buildings. 
Zsolt Gallina - Gyöngyi Gulyás • Glimpses into the Prehistory of Northeast-Hungary

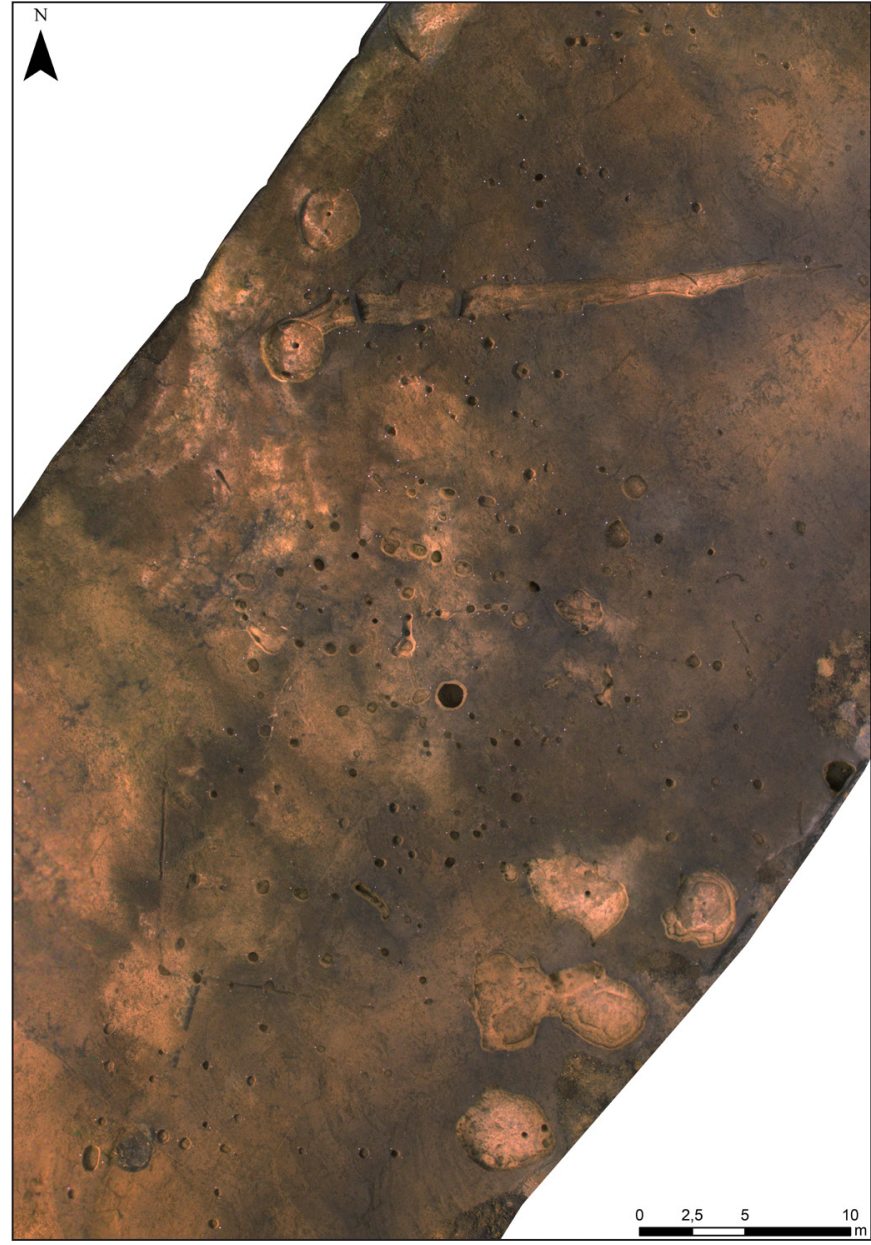

Fig. 11. Halmaj-Kiskinizsi-dülö, drone photo of negative underground structures (buildings supported by posts) (Photo by László Kolonits and Péter Czukor)

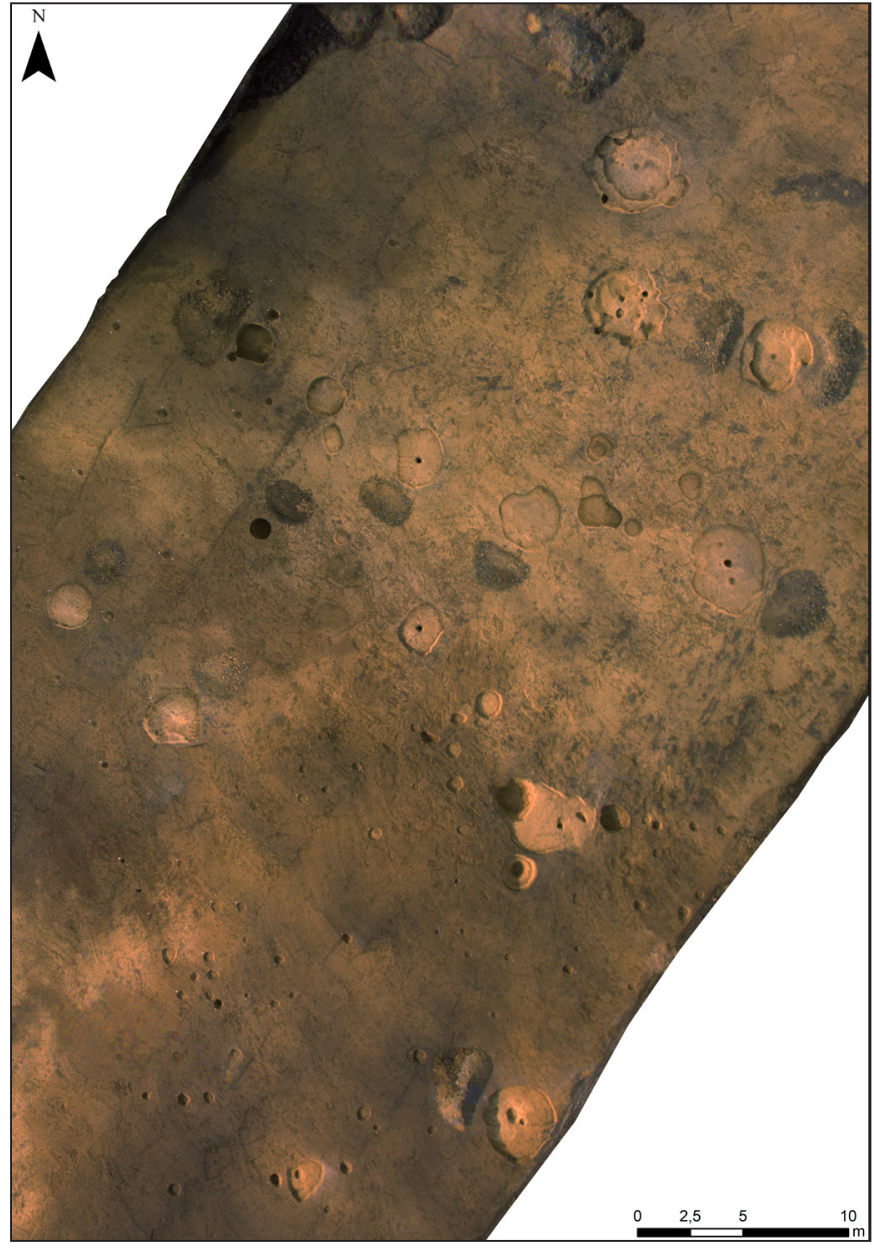

Fig. 12. Halmaj-Kiskinizsi-dülö, drone photo of the semi-subterranean buildings

(Photo by László Kolonits and Péter Czukor)

Based on analogies, such shallow, round pit structures can be identified as buldings associated with animal husbandry, as cabins used by haywards or shepherds (BÁRTH, 1982, Table 23; MATUZ, 1997, Figs. 8, 10.). Bones of ruminants and pigs suggest a stationary form of animal husbandry. Open pole structures may be interpreted as corrals or folds, while closed pole structures were sties or barns.

The excavation brought to light the settlement's periphery, the southern part of which was dominated by features associated with animal husbandry. The excavated settlement part can hypothetically be identified as a workshop and an animal keeping zone used during the night or as a backyard, close to the settlement's center. The northern side of the settlement was subdivided by a system of ditches. Here, features used for storage and raw material processing, as well as structures associated with locally fixed forms of animal husbandry, such as pigsties, round shepherd's cabins, and workshops, were uncovered. On the northern side, a stream called Büdös-kút provided access to water. It was customary to establish Scythian settlements on high banks close to water (Scholtz, 2010, p. 380). In his study on the Late Bronze Age and Iron Age settlement history of the Körös region, Gergely Bóka emphasizes that settlements of the Vekerzug Culture were typically located on high riverbanks and on parts of floodplains protected from the flood. A likely explanation is the dampness and coolness of the weather and the frequency of floods in the period (BóKA, 2010, pp. 61-62).

Based on these preliminary results, it is clear that a sedentary form of animal husbandry was predominant at the settlement; no traces of nomadic movements were observed. Members of this complex Scythian community probably also cultivated the land, processed local resoures (bone working, weaving, and milling) and were involved in a sedentary, complex way of farming in the Middle Iron Age (7/6-5/4 centuries BC). 
Zsolt Gallina - Gyöngyi Gulyás • Glimpses into the Prehistory of Northeast-Hungary

BIBLIOGRAPHY

BÁRTH, J., 1982.

Magyar népi épitészet. Budapest: Kolibri könyvek.

BÓKA, G., 2012.

Településtörténeti változások a Körös-vidéken a késő bronzkorban és a vaskorban. Vízrajz, térszínek és települések / Changes in settlement patterns in the Late Bronze and Iron Ages in the Körös Region. Hydrogeology, reliefs and settlements. In: A. Kreiter, Á. Pető \& B. Tugya, szerk. Környezet - Ember Kultúra. A természettudományok és a régészet párbeszéde / Environment - Human - Culture: Dialogue between Applied Sciences and Archaeology. Budapest: Hungarian National Museum - Centre for National Cultural Heritage, pp. 57-66.

Fábián, S., Marton, T., Serlegi, G., Hajdú, L. \& Köhler, K., 2017.

Erőszak és rítus a rézkorban: emberi maradványok Abony határában. Határtalan régészet, 2(2), pp. 25-28.

Gardner, W. R. M. \& Burentogtokh, J., 2018.

Mobile Domiciles of the Eurasian Steppe: Archaeological Evidence of Possible Dwelling Space during the Early Iron Age. Journal of Field Archaeology, 43(5), pp. 345-361. https://doi.org/10.1080/00934690.201 $\underline{8.1475994}$

GuBA, S., 2008.

A Pilinyi kultúra temetkezései Bercel-Sáfrányhegy II. lelőhelyén. Das Gräberfeld der Piliny-Kulturaus Bercel-Sáfrányhegy II. Nógrád Megyei Múzeumok Évkönyve 32, pp. 73-97.

Guba, S. \& Vaday, A., 2008.

Salgótarján, Bevásárlóközpont - többkorszakú régészeti lelőhely. Előzetes jelentés I. Salgótarján, Shopping centre: multi-period archaelogical site. Preliminary report I. In: Régészeti kutatások Magyarországon 2007. Budapest: Kulturális Örökségvédelmi Hivatal - Magyar Nemzeti Múzeum, pp. 11-34.

Hillebrand, J., 1929.

Újabb ásatásaim a zagyvapálfalvi bronzkori urnatemetőben. Über die neueren Ausgrabungen im bronzezeitlichen Urnengräberfeld von Zagyvapálfalva. Archaeologiai Értesító 43, pp. 35-40, 323-324.

HoRváth, T., 2004.

Emberi vázakat tartalmazó objektumok Balatonöszöd-Temetői dűlői badeni településről. Somogyi Múzeumok Közleményei 16, pp. 71-110.

HoRvÁth, T., 2006 [2007].

Állattemetkezések Balatonöszöd-Temetői dülői Badeni településröl. Animal-burials in the Late Copper Age Baden Site: Balatonöszöd-Temetői dülő. Somogyi Múzeumok Közleményei 17, pp. 107-152.

Kubarev, V., Tseveendorj, D. \& Jacobson, E., 2005.

Petroglify Cagaan-Salaa i Baga-Ojgura (Mongol’skij Altaj) [Петроглифы Цагаан-Салаа и Бага-Ойгура (МонгольскийАлтай)]. Novosibirsk - Ulaanbaatar.

Matuz, E., 1997.

Késő bronzkori és kora vaskori háztípusok és rekonstrukciós kísérleteik - Spätbronzezeitliche und früheisenzeitliche Häusertypen und ihre Rekonstruktionsversuche. Budapest Régiségei 31, pp. 211-227. 
Zsolt Gallina - Gyöngyi Gulyás • Glimpses into the Prehistory of Northeast-Hungary

Patay, P., 1954.

Elözetes jelentés a nagybátonyi temető ásatásának eredményeiről. Preliminary report on the results of excavations at Nagybátony cemetery. Archaeologiai Értesitö 81, pp. 33-49.

Scholtz, R., 2010.

Szkíták nyomában Magyarországon. In: Magyarország és Azerbajdzsán - a kultúrák párbeszéde. IV. Nemzetközi tudományos konferencia (Elöadások, cikkek, rezümék). Budapest: Azerbajdzsáni Köztársaság Magyarországi Nagykövetsége, pp. 379-398. 